\title{
BALANCE PROBLEMS IN DOWN SYNDROME CHILDREN: VARIOUS SENSORY ELEMENTS AND CONTRIBUTION TO MIDDLE EAR PROBLEMS
}

\author{
Amira El Shennawy \\ Otolaryngology, Audiology Unit, Kasr EL Ainy Hospital, Cairo University, Cairo, Egypt \\ Corresponding author: Amira El Shennawy, Otolaryngology, Audiology Unit, Kasr EL Ainy Hospital, Cairo \\ University, Cairo, Egypt, e-mail: amira.doc75@outlook.com
}

\begin{abstract}
Background: Down syndrome (DS) is one of the commonest causes of developmental delay in children, with equilibrium problems being an integral part of the syndrome. This leads to further impairment of cognitive and concentration abilities.

Material and methods: In our study, 30 DS children were categorized into 3 groups: bilateral normal middle ear pressure, bilateral abnormal middle ear pressure, and unilateral abnormal middle ear pressure. Sensory components of balance (somatosensory, visual, and vestibular) were assessed using computerized dynamic posturography.
\end{abstract}

Results: Results showed a statistically significant decrease in composite score, visual ratio, and vestibular ratio among DS children compared to normal children. No significant differences in sensory parameters between the various DS groups (with various tympanogram types) were encountered.

Conclusions: This might lead one to suspect central and proprioceptive causes behind balance problems in DS, but further extended studies are needed to confirm this. Bedside screening tests for visual and vestibular functioning of balance are recommended, e.g. past pointing and Fukuda for early detection and intervention.

Keywords: Down Syndrome • ear middle • postural balance

\section{PROBLEMAS DE EQUILIBRIO EN LOS NIÑOS CON EL SÍNDROME DE DOWN: SUS DISTINTOS COMPONENTES SENSORIALES Y LA RELACIÓN CON LAS ALTERACIONES EN EL OÍDO MEDIO}

\section{Resumen}

Introducción: El Síndrome de Down (Down syndrome, DS) es una de las causas más frecuentes del retraso del desarrollo de los niños con problemas de equilibrio, que, al mismo tiempo, es una parte integral de DS. Esto, a su vez, conduce a mayores dificultades en la adquisición de habilidades cognitivas y en la concentración.

Materiales y métodos: En nuestro estudio, 30 niños con el Síndrome de Down han sido divididos en 3 grupos: primer grupo con una presión bilateral normal en el oído medio, segundo grupo con la presión bilateral incorrecta en el oído medio, y un tercer grupo, con la presión unilateralmente incorrecta en el oído medio. Los componentes sensoriales del equilibrio (somatosensoriales, visuales y vestibulares) han sido evaluados mediante la posturografía computerizada dinámica.

Resultados: Los resultados demuestran una disminución estadísticamente significativa en el resultado total, del índice visual y vestibular, entre los niños con el Síndrome de Down, en comparación con los niños sanos. No se han observado diferencias significativas en los parámetros entre los tres grupos de personas con el DS (con distintos tipos de timpanogramas).

Conclusiones: Los resultados obtenidos indican que los trastornos centrales o kinestésicos pueden ser responsables de los problemas de equilibrio en el caso del síndrome de Down. Sin embargo, para confirmar este hallazgo, se necesitaría más investigación en profundidad. Para una detección e intervención tempranas, se recomiendan las pruebas de cribado de las funciones visuales y vestibulares de equilibrio, tales como, por ejemplo, past pointing y Fukuda,

Palabras clave: el Síndrome de Down (DS) • oído medio • balance corporal 


\section{ПРОБЛЕМЫ С РАВНОВЕСИЕМ У ДЕТЕЙ С СИНДРОМОМ ДАУНА: ИХ РАЗЛИЧНЫЕ СЕНСОРНЫЕ КОМПОНЕНТЫ И СВЯЗЬ С НАРУШЕНИЯМИ В СРЕДНЕМ УХЕ}

\section{Изложение}

Введение: Синдром Дауна (Down syndrome, DS) является одной из наиболее распространённых причин задержки развития детей с проблемами равновесия, которые, в свою очередь, являются неотъемлимой частью DS. Это приводит к дальнейшим сложностям в приобретении когнитивных навыков и концентрации.

Материал и методы: В нашем исследовании 30 детей с DS были разделены на 3 группы: с двусторонним нормальным давлением в среднем ухе, с двусторонним аномальным давлением в среднем ухе и с односторонним аномальным давлением в среднем ухе. Сенсорные компоненты равновесия (соматосенсорные, зрительные и вестибулярные) были оценены с помощью динамической компьютерной постурографии.

Результаты: Результаты показали статистически значимое снижение общего результата, зрительного и вестибулярного показателей среди детей с DS по сравнению со здоровыми детьми. Не отмечено существенной разницы в параметрах между группами лиц с DS (с различными типами тимпанограмм).

Выводы: Полученные результаты указывают, что центральные или кинестетические нарушения могут вызвать проблемы с равновесием в случае синдрома Дауна. Однако, чтобы подтвердить это утверждение, необходимы дальнейшие исследования. Рекомендуются скрининговые обследования по месту лечения зрительных и вестибулярных функций равновесия, напр. пальце-пальцевая проба и тест Фукуды, для более раннего обнаружения и вмешательства.

Ключевые слова: Синдром Дауна • среднее ухо • баланс тела

\section{PROBLEMY Z RÓWNOWAGĄ U DZIECI Z ZESPOŁEM DOWNA: ICH RÓŻNE KOMPONENTY ZMYSŁOWE ORAZ ZWIĄZEK Z ZABURZENIAMI W UCHU ŚRODKOWYM}

\section{Streszczenie}

Wprowadzenie: Zespół Downa (Down syndrome, DS) jest jednym z najczęstszych powodów opóźnienia rozwoju dzieci z problemami równowagi, które z kolei są nieodłączną częścią DS. Prowadzi to do dalszych trudności w zdobywaniu umiejętności poznawczych i koncentracji.

Materiał i metody: W naszym badaniu, 30 dzieci z DS zostało podzielonych na 3 grupy: z obustronnym prawidłowym ciśnieniem w uchu środkowym, obustronnym nieprawidłowym ciśnieniem w uchu środkowym, oraz jednostronnym nieprawidłowym ciśnieniem w uchu środkowym. Zmysłowe komponenty równowagi (somatosensoryczne, wzrokowe i przedsionkowe) były oceniane przy pomocy dynamicznej posturografii komputerowej.

Wyniki: Wyniki pokazały statystycznie istotny spadek wyniku łącznego, wskaźnika wzrokowego i przedsionkowego, wśród dzieci z DS w porównaniu z dziećmi zdrowymi. Nie zaobserwowano istotnych różnic w parametrach pomiędzy grupami osób z DS (z różnymi typami tympanogramów).

Wnioski: Uzyskane wyniki wskazują że zaburzenia centralne lub kinestetyczne mogą być odpowiedzialne za problemy z równowagą w przypadku zespołu Downa. Jednakże aby potwierdzić to stwierdzenie potrzebne są dalsze dogłębne badania. Zaleca się przyłóżkowe badania przesiewowe wzrokowych i przedsionkowych funkcji równowagi, np. past pointing i Fukuda, w celu wczesnego wykrycia oraz interwencji.

Słowa kluczowe: Zespół Downa • ucho środkowe • balans ciała

\section{Background}

Down syndrome (DS) is one of the most prevalent chromosomal disorders and is a cause for developmental delay in children [1]. In individuals with DS, inner ear dysplasia is common. Inner ear structures are universally hypoplastic and vestibular malformations are particularly common [2,3]. This may lead to equilibrium troubles and 
cognitive deficits. Poor concentration with impaired shortterm memory occurs frequently among patients with vestibular abnormalities $[4,5]$.

Disequilibrium in children with DS manifests as them having a wide support base, frequent falling, difficulty in everyday activities like walking without assistance, going downstairs, and moving in a dark environment [6].

Static standing and balance has been studied in DS cases (10-19 years old) under four conditions (C1: open-eyes/ fixed foot support; C2: closed eyes/fixed foot support; C3: open eyes/compliant foot support; C4: closed eyes/compliant foot support).To evaluate the contribution of each sensory system influencing postural control, ratios among the four conditions were calculated. Mean values of all conditions were higher in the cases than in the control group [8].

Another study in DS subjects also found an increase in frequency oscillation both in the anterior-posterior and medio-lateral directions $[6,7]$.

In DS, congenital anomalies of the Eustachian tube (ET) play an important role in the etiology of both otitis media and middle ear dysfunction, more so than in normal children. ET anomalies include: extreme smallness, collapse in the mid-cartilaginous isthmus and tympanic portions, and poorly developed lateral cartilage in the midcartilaginous portion [9].

The aim of this study is to assess the balance of individuals with DS in comparison to controls by measuring deficits in balance skills, and to compare balance in DS children who have normal or abnormal middle ear pressure.

\section{Material and methods}

Exactly 30 DS children (male and female) were selected from a clinic of children with special needs (National Research Centre) and the Hearing and Balance Unit Kasr ElAini Hospital, Cairo University, according to institutional policies and ethical approval.

Their ages ranged from 8-16 years. They were divided into 3 groups: group A included 13 DS children with bilateral normal middle ear pressure (or with ventilation tube insertion); group B comprised 12 DS children with bilateral abnormal middle ear pressure; and group $\mathrm{C}$ included 5 DS children with unilateral abnormal middle ear pressure. The sample size was considered a pilot study from which further replication studies could be done depending on its results.

The enrolled cases were subjected to clinical assessment in cluding medical history, otoscopic examination, and bedside clinical tests for vestibule-spinal tract integrity (past pointing, Romberg test, Fukuda test). Immitancemetry including tympanometry and acoustic reflexes was checked at frequencies of 500,1000,2000, and $4000 \mathrm{~Hz}$ was done using the Amplaid 720 immittancemeter.

Assessment of the three sensory components of balance (somatosensory, visual, and vestibular) was performed using computerized dynamic posturography (The Smart balance master, version 4 neurocom). This was done under a variety of altered visual and support surface conditions using a protocol for the sensory organization test (SOT). The SOT protocol involves six sensory conditions and objectively identifies abnormalities in the three sensory systems contributing to postural control: somatosensory, visual, and vestibular. Useful information delivered to the patient's eyes, feet, and joints is effectively eliminated through calibrated 'sway referencing' of the support surface and/or visual surrounds, which tilt to directly follow the patient's antero-posterior body sway. As a result, patients may display either an inability to make effective use of individual sensory systems, or inappropriate adaptive responses, resulting in the identification of inaccurate sense(s).

For each child, 18 trials of 20 seconds each were performed, giving three consecutive trials for each of the six sensory conditions. The first two sensory conditions were a standard Romberg test (i.e. eyes open and eyes closed on a fixed platform) while the other four conditions consisted of altered sensory conditions created by the visual surround and/or the platform.

The overall performance in SOT was described by a composite score which represents the average of the equilibrium scores [7], with a score of 70 or greater indicating normal.Sensory analysis ratios were used to identify possible impairments of individual sensory systems. The somato-sensory ratio (condition $2 /$ condition 1 ), visual ratio (condition 4 / condition 1), vestibular ratio (condition $5 /$ condition 1$)$ and the visual preference ratio $=$ (condition $3+6 /$ condition $2+5$ )

Statistical analysis was done with the statistical software package SPSS version 10. Chi-square tests, analyses of variance (ANOVA), and Bonferroni multiple comparisons tests were used, with a level of 0.05 indicating statistical significance.

\section{Results}

The three study groups displayed matching IQ scores (5070). Comparisons between normal children and DS children as regards the composite score and sensory responses were made. There was a statistically significant decrease in composite score in DS children compared to normal age matched children $(p=0.03$, Table 1$)$. Of the sensory parameters, the visual and vestibular ratios were significantly different among DS children compared to normal children, $(p=0.05$ and 0.01 respectively, Table 2$)$.

Acoustic reflex: was lost in all individuals of group B and $\mathrm{C}$ and in 9 children of group A with a significant statistical difference $(p=0.049)$.

Romberg test was only positive in one individual of group B while the Fukuda test was positive in 4 cases (2 in group $\mathrm{B}$ and 2 in group $\mathrm{C}$ ) with the difference not reaching statistical significance $(p=0.075)$.

The pastpointing test showed no statistically significant difference among the 3 groups with a $p$ value of 0.275 , with 3 children showing a positive result in each of the 3 groups. 
Table 1. Comparison between normal children and DS children for the sensory organization test (SOT) composite score

\begin{tabular}{ccccccc}
\hline & Group A & Group B & Group C & Normal & & $\boldsymbol{p}$-value \\
\cline { 2 - 5 } & Mean \pm SD & Mean \pm SD & Mean \pm SD & Mean \pm SD & & \\
\hline Composite score & $61.76 \pm 10.52$ & $60.83 \pm 8.21$ & $62.40 \pm 6.22$ & $69.10 \pm 6.81$ & 3.70 & $0.03^{*}$ \\
\hline
\end{tabular}

Table 2. Comparison of sensory analysis between normal children and Down syndrome (DS) children

\begin{tabular}{lcccc}
\hline & Normal children & DS children & \multicolumn{1}{c}{-test } \\
\cline { 2 - 5 } & Mean \pm SD & Mean \pm SD & $\boldsymbol{t}$ & $\boldsymbol{p}$-value \\
\hline Somatosensory ratio & $1.01 \pm 0.10$ & $1.01 \pm 0.10$ & 1.32 & 0.08 \\
\hline Visual ratio & $0.96 \pm 0.10$ & $0.74 \pm 0.18$ & 3.49 & $0.05^{\star}$ \\
\hline Vestibular ratio & $0.80 \pm 0.09$ & $0.59 \pm 0.19$ & 3.98 & $0.01^{*}$ \\
\hline Visual preference & $1.01 \pm 0.11$ & $0.95 \pm 0.10$ & 1.91 & 0.3 \\
\hline
\end{tabular}

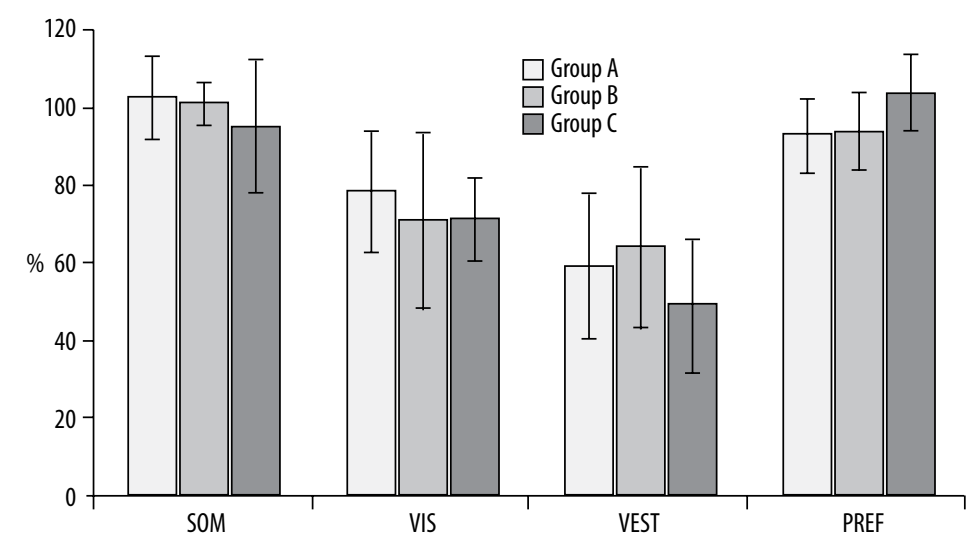

Figure 1. Comparison of sensory analysis between the three groups of Down syndrome children

The SOT between the 3 groups showed 28 cases to have some sort of abnormality. Vestibular ratio deficits (the most common posturographic abnormality) were found in 28 cases: 20 of the 28 had vestibular deficits alone and 8 cases had vestibular deficits in combination with other deficits. The second most common deficit was visual: 8 cases had visual deficits in combination with a vestibular ratio deficit. Somatosensory ratio or visual preference ratio abnormalities were not detected among our cases. Overall analysis showed no statistically significant difference in composite score and sensory analysis ratios between the three examined groups (Figure 1).

There was a positive correlation between the age of the patient and the composite test score in DS. However, there was no statistically significant correlation between the IQ test and the composite score in DS children. Further analysis of various parameters of sensory analysis and IQ and age in DS children was performed. There was a positive correlation between IQ and vestibular ratio $(p=0.037)$.

The correlation between bedside tests for balance and elements of SOT was examined. There was a positive correlation between the Fukuda test and somatosensory ratio and visual ratio ( $p=0.034$ and 0.02 respectively).
There was a statistically significant correlation between past pointing test and vestibular ratio and composite score ( $p=0.004$ and 0.022 respectively).

\section{Discussion}

Our study assessed balance in DS children and related it to middle ear problems in these children. Grouping of the examined children was based on middle ear function as indicated by a tympanogram. Ear, nose, and throat (ENT) problems are common in children with Down Syndrome (DS). These include problems with chronic ear infections and chronic middle ear effusions, airway obstruction, and sleep apnea, as well as problems with chronic rhinitis and sinusitis [11].

There was no significant difference between the 3 groups with different categories of tympanogram and Eustachian tube function, in SOT parameters which highlights other abnormalities as a cause of balance disturbances in DS, mainly inner ear and the proprioceptive system. This is in accordance with previous studies [12].

It would be of very useful to discover the aetiology of balance dysfunction in DS children and whether it relates to 
ear problems or other factors (e.g. cerebellar or proprioceptive problems). Our study revealed balance differences between DS and normal children with no significant difference in SOT parameters between the DS groups according to Eustachian tube function.

Further studies are needed to explore the balance difficulties in DS in relation to middle ear pressure. Previous studies in normal children have highlighted that otitis media is associated with balance disturbances ranging from true vertigo to mild ataxia in $22 \%$ of children with chronic middle ear problems. There seems to be no difference between unilateral and bilateral cases [13].

One of the interesting findings is the relationship between IQ score, visual orientation, and balance disorders. Our results shows that, when considering the overall composite score, an influential factor that increases balance problems in DS children is a significantly negative relation between IQ level and vestibular score. A previous study showed that in DS, visual orienting behaviour and visual processing time were mainly affected by IQ level and age [14]. Our data are noteworthy in showing a correlation between vestibular function and IQ. There was a statistically significant difference in vestibular ratio between DS children and normal children and also a positive correlation between IQ and vestibular ratio $(p=0.037)$ in DS children.

Our results showed significantly reduced composite score in DS children when compared to normal children, which highlights motor problems that might result from impaired postural control (due to vestibular dysfunction), trunkal hypotonia, and increased body mass index that is predominant in DS [15].

Furthermore we found a difference in balance parameters between DS and age-matched control children, with the past pointing test positively correlating with vestibular and composite scores. The Fukuda test positively correlated with somatosensory and vestibular scores. Therefore, both tests are good indicators of balance disturbances. Hence, they can be used as bedside preliminary tests in those children to screen balance problems before further detailed sensory assessment.

\section{Conclusions}

In conclusion, the current study shows that sensory analysis of balance using SOT in DS and an age-matched control group shows a significant difference in visual and vestibular function.

No differences were found in sensory parameters of SOT in DS children that were grouped according to tympanogram type, which suggests central and proprioceptive reasons behind balance problems in these children. This finding should be further extended to studies of DS children of different ages. We also recommend using some screening tools for balance in DS children, for example, Fukuda test, gaze stabilization test, and eye movement analysis.

\section{References:}

1. Zhu J, Hasle H, Correa A, Schendel D, Friedman J, Olsen J et al. Survival among people with Down syndrome: a nationwide population-based study in Denmark. Genet Med, 2013; 15(1): 64-9.

2. Blaser S, Propst E, Martin D, Feigenbaum A, James A, Shannon $\mathrm{P}$ et al. Inner ear dysplasia is common in children with Down syndrome (trisomy 21). Laryngoscope, 2006; 116(12): 2113-9.

3. Coppens MC, Maassen BAM, van Schrojenstein Lantman-de Valk HMJ, Snik AFM. Hearing disorders and auditory speech processing difficulties in adults with Down syndrome: a review of the literature. J Hear Sci, 2011; 1(3): RA11-17.

4. Hanes D, McCollum G. Cognitive-vestibular interactions: a review of patient difficulties and possible mechanisms. J Vestib Res, 2006; 16(3): 75-91.

5. Coppens-Hofman MC, Maassen BAM, van Schrojenstein Lantman-deValk HMJ, Snik AFM. Speech difficulties and poor speech intelligibility in adults with Down syndrome: a review of the literature. J Hear Sci, 2012; 2(1): RA9-16.

6. Galli M, Rigoldi C, Mainardi L, Tenore N, Onorati P, Albertini G. Postural control in patients with Down syndrome. Disabil Rehabil, 2008; 30(17): 1274-8.

7. Driscoll C, Kei J, Hearn K, Walsh T, Swann S. Diagnostic accuracy of high-frequency distortion-product otoacoustic emission screening of schoolchildren with Down syndrome. J Hear Sci, 2014; 4(1): OA9-17.
8. Villarroya MA, González-Agüero A, Moros-García T, de la Flor Marín M, Moreno LA, Casajús JA. Static standing balance in adolescents with Down syndrome. Res Dev Disabil, 2012; 33(4): 1294-300.

9. Miura M, Sando I, Balaban CD, Haginomori S, Orita Y. Temporal bone morphometric study on the eustachian tube and its associated structures in patients with chromosomal aberrations. Ann Otol Rhinol Laryngol, 2002; 111(8): 722-9.

10. Wolf SL, Barnhart HX, Ellison GL, Coogler CE. The effect of Tai Chi Quan and computerized balance training on postural stability in older subjects. Atlanta FICSIT Group. Frailty and Injuries: Cooperative Studies on Intervention Techniques. Phys Ther, 1997; 77(4): 371-81.

11. Rodman R, Pine HS. The otolaryngologist's approach to the patient with Down syndrome. Otolaryngol Clin North Am, 2012; 45(3): 599-629.

12. Carvalho RL, Almeida GL. The effect of vibration on postural response of Down syndrome individuals on the seesaw. Res Dev Disabil, 2009; 30(6): 1124-31.

13. Casselbrant ML, Villardo RJ, Mandel EM. Balance and otitis media with effusion. Int J Audiol, 2008; 47(9): 584-9.

14. Boot FH, Pel JJ, Evenhuis HM, van der Steen J. Factors related to impaired visual orienting behavior in children with intellectual disabilities. Res Dev Disabil, 2012; 33(5): 1670-6.

15. Wuang YP, Su CY. Correlations of sensory processing and visual organization ability with participation in school-aged children with Down syndrome. Res Dev Disabil, 2011; 32(6): 2398-407. 